\title{
Dlaczego zaleca się stosowanie profesjonalnych ośrodków sprzęgających w badaniach ultradźwiękowych?
}

\author{
Why is it recommended to use professional coupling agents \\ during ultrasonic examination?
}

\section{Streszczenie}

Ośrodki sprzęgające pełnią $\mathrm{w}$ badaniach ultradźwiękowych niezwykle ważną rolę, umożliwiając przejście fali ultradźwiękowej z jednego ośrodka do drugiego. Dla prawidłowego przeprowadzenia procesu badania istotny jest dobór odpowiedniego sprzęgacza. W poniższym referacie przedstawiono wpływ impedancji akustycznych ośrodków sprzęgających na wysokość amplitudy echa, a także ich zależności od współczynnika tłumienia. Na podstawie analizy dostępnych materiałów stwierdzono zmniejszanie się wysokości echa dna oraz współczynnika tłumienia wraz ze spadkiem impedancji akustycznej sprzęgaczy dla tego samego poziomu wzmocnienia. W pracy przedstawiono również wpływ sprzęgacza na powstawanie zjawiska korozji w badanym materiale.

Słowa kluczowe: badania nieniszczące; badania ultradźwiękowe; sprzęgacz

\begin{abstract}
Coupling agents are very important in ultrasonic testing - they let the wave to transmit across the interface, from a transducer to a test material. Choosing the right couplant is of great significance for the whole examination process. In this paper, various couplants and their influence on the amplitude of back wall echoes and attenuation coefficients are presented. It was observed, that the amplitude of back wall echo and attenuation coefficient were decreasing with the acoustic impedance of used couplants - these relations were linear. This paper contains also information about how big is the influence of couplant type on corrosion process forming and spreading on examined material.
\end{abstract}

Keywords: NDT; ultrasonics; couplant

\section{Wstęp}

Do prawidłowego procesu badań ultradźwiękowych trzeba przede wszystkim zlokalizować miejsce badania, dobrać i wyskalować właściwy zestaw „defektoskop-głowica”, a także dobrać odpowiedni sprzęgacz, aby wyeliminować powietrze między głowicą i powierzchnią obiektu oraz umożliwić przejście wiązki ultradźwiękowej z jednego ośrodka do drugiego [1]. Ośrodek sprzęgający, mimo, że jest jednym z istotniejszych elementów w całym procesie badawczym, jest traktowany przez operatorów jako niezbędny, ale często do jego wyboru nie przywiązuje się większej uwagi. Źle dobrany sprzęgacz może utrudnić prowadzenie badań i klasyfikację wad, ale również wywołać zjawisko korozji na badanym materiale.

\section{Kryteria doboru odpowiedniego sprzęgacza}

Istnieje wiele czynników, które mogą wpływać na właściwy wybór sprzęgacza przez operatora. Poniżej przedstawiono kryteria, którymi należy kierować się (wg. M. Larssona [2]) przy doborze sprzęgacza, aby przeprowadzić prawidłowy proces badawczy.

1) Inhibitory korozji i składniki niedozwolone

Niewłaściwie dobrany sprzęgacz, pozostawiony na powierzchni badania, może powodować i przyspieszać pojawienie się korozji w materiale, w tym tak niebezpiecznej korozji wżerowej, wodorowej czy naprężeniowej. Stosując różnego rodzaju substancje jako ośrodki sprzęgające należy sprawdzić czy mogą być one stosowane na powierzchniach metalicznych - czy zawierają niedozwolone pierwiastki lub związki oraz zalecane inhibitory korozji (związki chemiczne zatrzymujące i spowalniające procesy korozyjne).Należy zwrócić także uwagę na zachowanie czystości badanego materiału po zakończeniu inspekcji. O ile pozostawienie sprzęgacza zawierającego inhibitory korozji na elemencie nie spowoduje jego skorodowania (w niektórych przypadkach może być nawet doskonałą ochroną antykorozyjną), o tyle substancja nieprzystosowana do badań metali może wywołać korozję szybko lub dopiero po jakimś czasie (często medium np. w zbiornikach staje się katalizatorem przyspieszającym reakcje korozyjne).

\section{2) Impedancja akustyczna}

Jest to wielkość charakterystyczna dla określonego rodzaju ośrodka i fali wyrażona wzorem:

$$
z=\rho c \quad\left[\frac{k g}{m^{2} s}\right]
$$

Mgr inż. Rafał Obłąkowski; mgr inż. Marek Lipnicki - Koli Sp. z o.o.

Autor korespondencyjny/Corresponding author: roblakowski@koli.eu 
gdzie:

$\rho$ - gęstość ośrodka $\left[\mathrm{kg} / \mathrm{m}^{3}\right]$

c - prędkość rozchodzenia się danego rodzaju fali w określonym ośrodku [m/s].

Im większa impedancja akustyczna ośrodka sprzęgającego tym większa redukcja szumów akustycznych, wynikających z chropowatości powierzchni, i lepsze sprzęganie na chropowatych i nierównych powierzchniach [1].

\section{3) Lepkość}

Większa lepkość ośrodka sprzęgającego zapewnia większą redukcję szumów i lepsze sprzęganie na nierównych powierzchniach. Odpowiednia lepkość sprzęgacza powinna zostać wybrana na podstawie trzech czynników:

- wystawienie na działanie czynników zewnętrznych (kapanie z górnej powierzchni),

- przyczepność do badanego elementu (np. na powierzchni pionowej),

- łatwość użycia (sposób nanoszenia sprzęgacza na powierzchnię badaną).

\section{4) Zakres temperatury}

Wybór ośrodka sprzęgającego zależy przede wszystkim od temperatury obiektu i czasu badania oraz czy zostanie on pozostawiony na obiekcie (degradacja, toksyczność, itp.).

\section{5) Czas wysychania i szybkość odparowywania}

Te parametry są istotne zwłaszcza, gdy czas trwania inspekcji jest długi. Wyższe temperatury przeznaczenia sprzęgacza wiążą się z dłuższym czasem jego wysychania.

\section{Podstawy teoretyczne}

\section{Współczynniki odbicia i transmisji}

Energia fali odbitej i przepuszczonej na granicy ośrodków jest zależna od ich impedancji akustycznych. Można zatem przyjąć, że impedancja akustyczna ośrodków będzie decydowała o tym jak duża część fali zostanie odbita od granicy sąsiadujących ze sobą materiałów, a jaka część przeniknie do jednego z nich [3].

Impedancja akustyczna pozwala na wyznaczenie współczynników odbicia i transmisji na granicy ośrodków, które są wyrażone wzorami [1]:

$$
\begin{gathered}
R_{I}=\left(\frac{Z_{1}-Z_{2}}{Z_{1}+Z_{2}}\right)^{2} \\
T_{I}=1-R_{1}=\frac{4 Z_{1} Z_{2}}{\left(Z_{1}+Z_{2}\right)^{2}}
\end{gathered}
$$

gdzie:

$\mathrm{R}$ - współczynnik odbicia

T - współczynnik transmisji (przenikania)

$\mathrm{Z}_{1}$ - impedancja akustyczna ośrodka $\mathrm{nr} 1$

$\mathrm{Z}_{2}$ - impedancja akustyczna ośrodka nr 2

Współczynniki odbicia i transmisji wyrażone wzorami 2 oraz 3 są prawdziwe tylko dla sytuacji teoretycznej, w której w kontaktowych badaniach ultradźwiękowych nie bierze się pod uwagę warstwy sprzęgacza (rys. 1a) pomiędzy głowicą a badanym materiałem.

W rzeczywistych ultradźwiękowych badaniach kontaktowych pomiędzy głowicą a badanym materiałem musi występować zawsze warstwa sprzęgacza o grubości d. W takim przypadku współczynnik transmisji przyjmie wartość wyrażoną (po uproszczeniu) wzorem:

$$
T_{I} \cong \frac{4}{A+B\left(\frac{k_{2} d}{Z_{2}}\right)^{2}}
$$

gdzie: $\quad A=\frac{\left(z_{1}+z_{3}\right)^{2}}{z_{1} z_{3}}, B=z_{1} z_{3}, k_{2}-$ liczba falowa
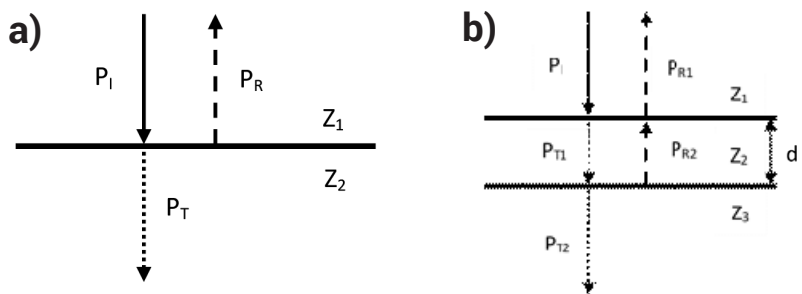

Rys. 1. Zjawiska odbicia i transmisji fali, zachodzące na granicy ośrodków powietrze-próbka: a) schemat teoretyczny, nierzeczywisty, nie uwzględnia warstwy sprzęgacza pomiędzy powietrzem a badanym materiałem; b) schemat rzeczywisty, z uwzględnieniem warstwy sprzęgacza o grubości d; $P_{1}$ - fala padająca na granicę ośrodków; $\mathrm{P}_{\mathrm{T} 1}, \mathrm{P}_{\mathrm{T} 2}$ - fala, która uległa transmisji do ośrodka; $\mathrm{P}_{\mathrm{R} 1}$, $\mathrm{P}_{\mathrm{R} 2}$ - fala odbita od granicy ośrodków

Fig. 1. Transmission and reflection of plane waves on the air-material interface: a) theoretical scheme, unreal, does not include a layer of couplant between air and the specimen; b) real scheme, including a layer of couplant of thickness $d_{;} P_{1}$ - incident wave onto airmaterial interface; $\mathrm{P}_{\mathrm{T} 1}, \mathrm{P}_{\mathrm{T} 2}$ - the wave transmitted into material; $\mathrm{P}_{\mathrm{R} 1}$, $\mathrm{P}_{\mathrm{R} 2}$ - the wave reflected from the media interface

W popularnych badaniach prowadzanych głowicą normalną fal podłużnych, grubość warstwy sprzęgacza, znajdującego się pomiędzy głowicą a badanym materiałem, jest znacznie mniejsza od długości wysyłanej fali, a jego impedancja akustyczna jest mniejsza od impedancji akustycznej materiału oraz głowicy. W związku z tym, że impedancje akustyczne głowicy i materiału są stałe, współczynnik transmisji będzie zależał od długości wysyłanej fali oraz grubości i impedancji akustycznej ośrodka sprzęgającego [4].

\section{Współczynnik tłumienia}

Wraz z propagacją fali w materiale zmniejsza się jej ciśnienie, co skutkuje spadkiem wartości amplitudy echa dna. Zjawisko to jest spowodowane absorpcją i rozpraszaniem, które mają wpływ na wielkość współczynnika tłumienia:

$$
\alpha=\alpha_{p}+\alpha_{r}
$$

Współczynniki $\alpha_{\mathrm{p}} \mathrm{i} \alpha_{\mathrm{r}}$ są odpowiednio współczynnikiem pochłaniania (absorpcji) oraz współczynnikiem rozpraszania. Wyraża się je za pomocą wzorów:

$$
\begin{gathered}
\alpha_{p}=C_{1} f \\
\alpha_{r}=C_{2} f^{4} D^{3}
\end{gathered}
$$

gdzie:

$C_{1}, C_{2}$ - stałe charakterystyczne dla danego materiału

$f \quad$ - częstotliwość fali

D - rozmiar ziarna

Współczynnik tłumienia definiuje się jako wartość zmniejszenia amplitudy ciśnienia (wysokości impulsu) przypadającą na jednostkę długości drogi fali w danym ośrodku [1]. Wartość amplitudy $A$ fali po przebyciu drogi $x$ będzie zatem wyrażona wzorem:

$$
A=A_{0} e^{-\alpha x}
$$

gdzie:

$A_{0}$ - początkowa wartość amplitudy

$\alpha-$ współczynnik tłumienia materiału $[3,4]$

Do obliczenia współczynnika tłumienia wykorzystuje się porównanie amplitud kolejnych ech dna materiału. Jeżeli wykorzystujemy metodę impulsową kontaktową dla pomiaru echa dna próbki, ośrodek sprzęgający będzie miał wpływ na wysokość amplitud otrzymanych ech dna w stopniu określonym przez równanie 4 oraz współczynnik tłumienia. Zależność amplitudy echa od współczynników odbicia i transmisji można wyrazić poprzez natężenie wysłanej wiązki. Stwierdzono, że natężenie I wysłanej fali jest wprost proporcjonalne do kwadratu amplitudy otrzymanego echa 
- I $\propto A^{2}$. Zatem natężenie pierwszego i drugiego echa dna będą wynosiły odpowiednio:

$$
\begin{gathered}
I_{1}=I_{0} T_{I}^{2} e^{-4 \alpha x} \\
I_{2}=I_{0} T_{I}^{2} R_{I} e^{-8 \alpha x}
\end{gathered}
$$

gdzie:

$T_{1}$ - natężeniowy współczynnik transmisji

$R_{1}$ - natężeniowy współczynnik odbicia [4]

W badaniach ultradźwiękowych, w celu porównania wysokości impulsów, amplitudy ciśnień czy wielkości wad, wykorzystuje się skalę decybelową [1]. Jest ona stosowana także do wyznaczenia współczynnika tłumienia. Dla próbki o grubości h, podczas badań ultradźwiękowych metodą impulsową, pozorny współczynnik tłumienia będzie określony za pomocą wzoru:

$$
\alpha^{\prime}=20 \frac{1}{2 h} \log \frac{A_{1}}{A_{2}}
$$

gdzie:

$A_{1}, A_{2}$ - amplituda pierwszego i drugiego echa dna

$h$ - grubość próbki

W powyższym wzorze nie zostało uwzględnione oddziaływanie fali ultradźwiękowej z ośrodkiem sprzęgającym. W praktyce cienka warstwa sprzęgacza zawsze występuje, a współczynniki transmisji i odbicia będą miały wpływ na wielkość otrzymanej amplitudy [4]. Po uwzględnieniu warstwy sprzęgacza, rzeczywisty współczynnik tłumienia powinien być wyrażony za pomocą wzoru:

$$
\alpha=20 \frac{1}{2 h} \log \left(\sqrt{R_{I}} \frac{A_{1}}{A_{2}}\right)
$$

W celu uwidocznienia różnicy pomiędzy pozornym a rzeczywistym współczynnikiem tłumienia, wzory 11 oraz 12 zostały porównane i stąd:

$$
\alpha^{\prime}=\alpha-\frac{5}{h} \log R_{I}
$$

Zatem współczynnik odbicia $R_{1}$ będzie zawsze mniejszy od 1, a funkcja $\log R_{1}$ będzie przyjmowała wartości ujemne. Oznacza to, że pozorny współczynnik tłumienia będzie większy od rzeczywistego współczynnika tłumienia o wartość $5 / h \log R_{1}[1,4]$.

\section{Wyniki badań}

Powyżej przytoczono podstawy teoretyczne i opisano jakimi kryteriami należy kierować się przy wyborze ośrodka sprzęgającego oraz jaki jest jego teoretyczny wpływ na przebieg i wyniki prowadzonych badań ultradźwiękowych.

Poniższe wyniki badań eksperymentalnych przedstawiają wpływ ilościowy oraz jakościowy na przebieg badań ultradźwiękowych przy zastosowaniu różnych sprzęgaczy. Dodatkowo pokazano wpływ sprzęgaczy, tych profesjonalnych i tych „popularnych”, na wywoływanie zjawiska korozji. Wyniki wszystkich eksperymentów pochodzą z artykułów i opracowań wymienionych w Literaturze.

\section{Wpływ rodzaju ośrodka sprzęgającego na przebieg badań ultradźwiękowych}

Ośrodki sprzęgające na bazie wody i gliceryny, o różnych proporcjach oraz ich wpływ na amplitudę i współczynnik tłumienia [4]

Przeprowadzono eksperyment impulsową metodą ultradźwiękową echa przy zastosowaniu głowicy normalnej fal podłużnych. Na potrzeby doświadczenia przygotowano 11 próbek ośrodka sprzęgającego na bazie wody i gliceryny, z których każda miała inne proporcje tych składników. Szczegółowe informacje na temat ośrodków sprzęgających przedstawia tablica I.
Tablica I. Oznaczenie i charakterystyka wykorzystanych ośrodków sprzęgających

Table I. Couplants used and their properties

\begin{tabular}{|c|c|c|c|c|}
\hline $\begin{array}{c}\text { Oznaczenie } \\
\text { sprzęgacza }\end{array}$ & $\begin{array}{c}\text { Stosunek } \\
\text { woda: } \\
\text { gliceryna }\end{array}$ & $\begin{array}{c}\text { Gęstość } \\
{\left[\mathbf{k g} / \mathbf{m}^{3}\right]}\end{array}$ & $\begin{array}{c}\text { Prędkość } \\
{[\mathbf{m} / \mathbf{s}]}\end{array}$ & $\begin{array}{c}\text { Impedancja } \\
\text { akustyczna } \\
\text { (x106 kg/ } \\
\mathbf{m} 2 \mathbf{s})\end{array}$ \\
\hline $\mathbf{C}$ & $\mathbf{1 0 : 0}$ & 998 & 1490 & 1,49 \\
\hline C2 & $9: 1$ & 1018 & 1533 & 1,56 \\
\hline C3 & $8: 2$ & 1039 & 1586 & 1,65 \\
\hline C4 & $7: 3$ & 1065 & 1637 & 1,74 \\
\hline C5 & $6: 4$ & 1089 & 1685 & 1,84 \\
\hline C6 & $5: 5$ & 1113 & 1739 & 1,94 \\
\hline C7 & $4: 6$ & 1141 & 1790 & 2,04 \\
\hline C8 & $3: 7$ & 1173 & 1836 & 2,15 \\
\hline C9 & $2: 8$ & 1195 & 1863 & 2,23 \\
\hline C10 & $1: 9$ & 1224 & 1895 & 2,32 \\
\hline C11 & $\mathbf{0 : 1 0}$ & 1260 & 1920 & 2,42 \\
\hline
\end{tabular}

Wykorzystano próbki ze stali węglowej $\left(\mathrm{c}_{\mathrm{L}}=5960 \mathrm{~m} / \mathrm{s}\right)$ i z nierdzewnej stali wysokostopowej ( $\left.\mathrm{c}_{\llcorner}=5600 \mathrm{~m} / \mathrm{s}\right)$. Użyta głowica normalna fal podłużnych miała przetwornik o średnicy $12,7 \mathrm{~mm}$ oraz częstotliwość $5 \mathrm{MHz}$ i pozostawała w kontakcie $z$ badanym materiałem. Obraz był tak wyskalowany, aby mógł wyświetlić 4 impulsy echa dna. Pomiędzy głowicę i materiał badany wsuwano cienką folię aluminiową $(16 \mu \mathrm{m})$ dla zachowania stałej grubości warstwy sprzęgacza (folię umieszczono tak, aby jej obecność nie wpływała na przebieg badań ultradźwiękowych). Na rysunku 2 przedstawiono echa dna dla stali węglowej przy sprzężeniu czystą wodą i gliceryną. Pierwsze echo było utrzymane na poziomie $80 \%$ wysokości ekranu. Wzmocnienie dla wody musiało być wyższe o $5 \mathrm{~dB}$ od wzmocnienia przy zastosowaniu gliceryny. a)

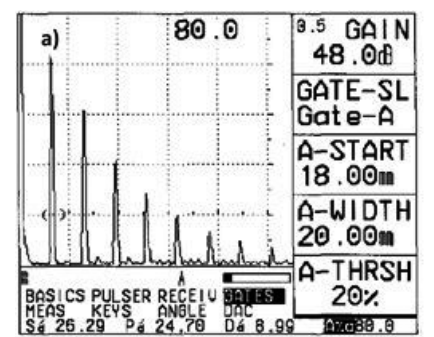

b)

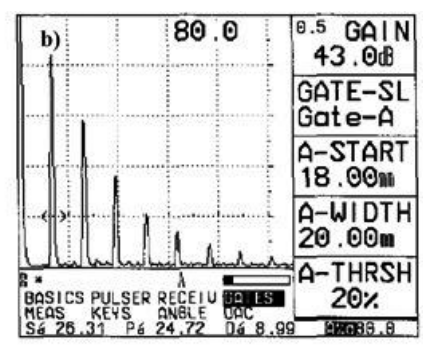

Rys. 2. Otrzymane echa dna przy użyciu jako ośrodka sprzęgającego: a) wody, b) gliceryny

Fig. 2. Backwall echoes obtained by using different couplants: a) water, b) glicerine

Zależności wielkości amplitudy echa dna od impedancji akustycznej sprzęgacza dla stali węglowej i nierdzewnej zostały przedstawione na rysunku 3 . Amplituda echa dna dla sprzężenia przez glicerynę jest niemal trzykrotnie wyższa niż, gdy ośrodkiem sprzęgającym była woda.

Zatem za spadek wartości amplitudy odpowiada właśnie ośrodek sprzęgający, co jest zgodne ze wzorem 4. Wartości amplitudy są większe dla stali węglowej niż dla stali nierdzewnej, ponieważ współczynnik tłumienia jest większy dla stali nierdzewnej.

Pozorny współczynnik tłumienia w zależności od impedancji akustycznej ośrodków sprzęgających przedstawia rysunek 4. Zgodnie z przewidywaniami, wraz ze wzrostem 
impedancji akustycznej rośnie pozorny współczynnik tłumienia - dla czystej gliceryny jest on około dwa razy większy niż dla wody.

Zgodnie ze wzorem 13, pozorny współczynnik tłumienia zależy od natężeniowego współczynnika odbicia na granicy dwóch ośrodków - głowicy i materiału badanego. Biorąc to pod uwagę, możliwe jest obliczenie rzeczywistego współczynnika tłumienia - wyniki przedstawia rysunek 5. Wykazano, że rzeczywisty współczynnik tłumienia przyjmuje stałą wartość dla danego typu materiału, niezależnie od impedancji akustycznej ośrodka sprzęgającego.

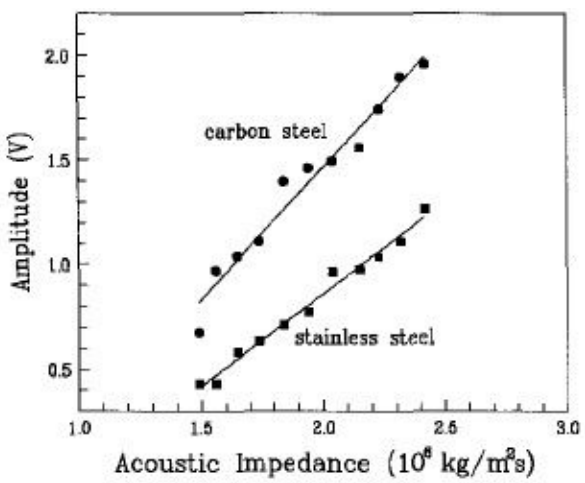

Rys. 3. Zależność amplitudy pierwszego echa dna od impedancji akustycznej danego rodzaju sprzęgacza dla stali węglowej i nierdzewnej

Fig. 3. Relation between the amplitude of the first backwall echo and the acoustic impedance of each couplant type for carbon steel and stainless steel

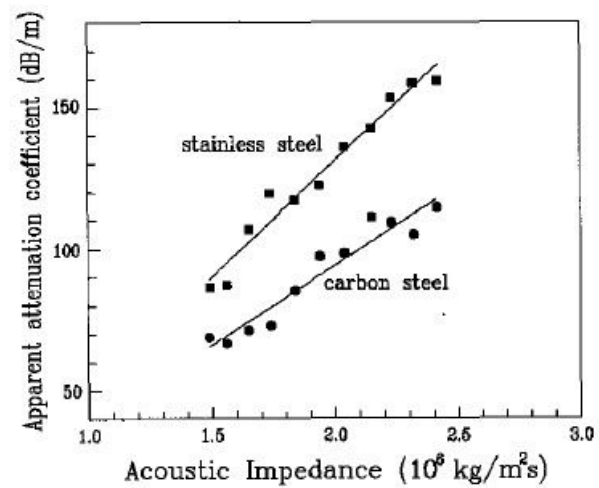

Rys. 4. Wartości pozornych współczynników tłumienia w zależności od impedancji akustycznych sprzęgaczy (różne proporcje wodagliceryna)

Fig. 4. Relation between the apparent attenuation coefficients and the acoustic impedance of each couplant type for carbon steel and stainless steel

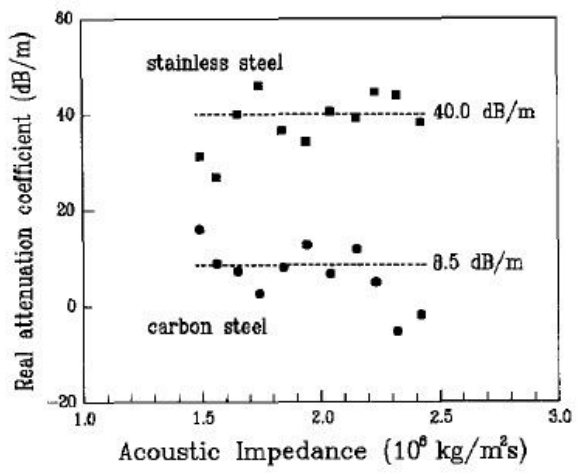

Rys. 5. Zależność rzeczywistych współczynników tłumienia od impedancji akustycznych ośrodków sprzęgających

Fig. 5. Relation between the real attenuation coefficients and the acoustic impedance of each couplant type for carbon steel and stainless steel

\section{Ośrodek sprzęgający wywoływaczem korozji?}

"Primum non nocere”, czyli „po pierwsze nie szkodzić” to słowa przysięgi Hipokratesa, które po dziś dzień wypowiadają studenci uczelni medycznych. Sentencja ta powinna odnosić się również, jak sama nazwa wskazuje, do badań nieniszczących. W przypadku badań ultradźwiękowych jednym z zagrożeń dla obiektu badanego jest zjawisko korozji spowodowane źle dobranym ośrodkiem sprzęgającym. Nieodpowiedni skład sprzęgacza (brak tzw. inhibitora korozji) i pozostawienie go na powierzchni badanej po zakończeniu inspekcji może zapoczątkować proces korozji, albo przyspieszyć propagację już istniejących wżerów.

Niżej przedstawione badania praktyczne pokazują jak duży wpływ na niszczenie materiału badanego może mieć źle dobrany sprzęgacz i jak istotne jest stosowanie profesjonalnych ośrodków sprzęgających. Badania te przeprowadziły firmy Sonatest i Sonotech dla potrzeb klientów tych firm.

\section{Badanie wpływu ośrodka sprzęgającego na powstanie zjawiska korozji [5]}

Badania miały na celu wykazanie wpływu rodzaju ośrodka sprzęgającego na wywołanie zjawiska korozji na powierzchni badanej. W doświadczeniu wykorzystano profesjonalny żel ultradźwiękowy Sonagel-W oraz klej do tapet. Eksperyment prowadzono na wzorcu nr 1.

Doświadczenie składało się z dwóch części. W pierwszej wzorzec nr 1 podzielono na 3 sekcje - na pierwszy obszar na-

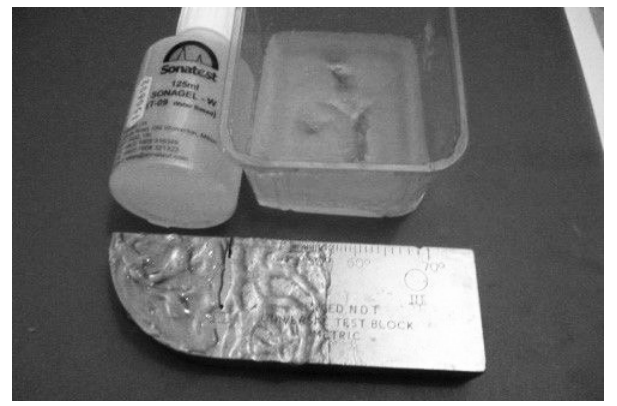

Rys. 6. Wzorzec $\mathrm{nr} 1$ wraz z wydzielonymi obszarami, na które naniesiono (od lewej) sprzęgacz Sonagel-W, klej do tapet oraz obszar, którego powierzchnia pozostała czysta

Fig. 6. Calibration block no 1 with separated areas; (from the left) the first area is covered with professional couplant Sonagel-W, the second area is covered with a wallpaper glue and the third area remains clean

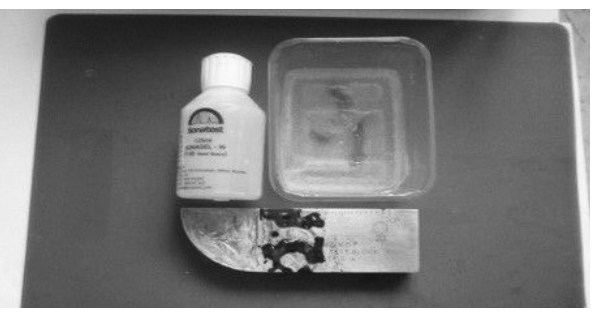

Rys. 7. Wyniki eksperymentu po upływie 12 godz.

Fig. 7. Experiment results after $12 \mathrm{~h}$.

łożono sprzęgacz Sonagel-W, na drugi klej do tapet, a trzeci (z prawej) pozostawiono czysty (rys. 6). Skutki eksperymentu po 12 godzinach pokazuje rysunek 7 .

Zaobserwowano, że już przed upływem 12 godzin, w miejscu, na które nałożono klej do tapet, powierzchnia próbki zaczęła korodować. Warto zauważyć, że stan powierzchni na pozostałych dwóch obszarach nie uległ zmianie.

W drugiej części eksperymentu usunięto z próbki nałożone wcześniej sprzęgacze i wystawiono ją na działanie czynników atmosferycznych przez 4-5 dni. Efekty doświadczenia można zaobserwować na rysunku 8. 


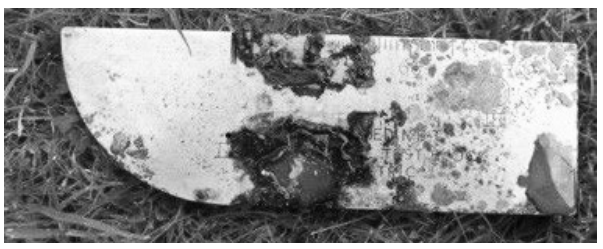

Rys. 8. Zdjęcie próbki wykonane po 4-5 dniach od rozpoczęcia doświadczenia

Fig. 8. Photo of the calibration block no 1 taken after 4-5 days since the experiment had begun

Na podstawie otrzymanych wyników badań stwierdzono, że po upływie 4-5 dni obszarem najbardziej skorodowanym było miejsce, na które wcześniej nałożono klej do tapet. Co ciekawe, powierzchnia, która nie była pokryta warstwą sprzęgacza była bardziej skorodowana od sekcji pokrytej profesjonalnym żelem ultradźwiękowym Sonagel-W. Jest to spowodowane tym, że profesjonalne ośrodki sprzęgające do badań ultradźwiękowych są jednocześnie inhibitorami korozji, które nie tylko spowalniają, ale i powstrzymują powstanie korozji.

\section{Badanie wpływu dodatku inhibitora korozji [2]}

Przeprowadzone badania miały na celu sprawdzenie ośrodka sprzęgającego pod względem inhibicji korozji. Mechanizmy powstawania korozji szczelinowej i powierzchniowej znacząco różnią się, dlatego doświadczenie zakłada wywołanie obu rodzajów korozji. Wykorzystano próbkę wykonaną z niskostopowej stali 1018, której powierzchnia została dokładnie oczyszczona. Następnie na próbkę naniesiono 2 krople ośrodka sprzęgającego. Jedna z kropel została przykryta szklaną płytką co miało imitować warunki sprzyjające korozji szczelinowej. Druga kropla miała wywołać korozję powierzchniową. Próbę wykonano dla dwóch różnych ośrodków sprzęgających - dla profesjonalnego żelu Ultragel-II oraz dla ośrodka bez inhibitora korozji. Wyniki badań przedstawia rysunek 9.

Eksperyment wykazał, że czynnikiem wywołującym powstanie korozji jest zastosowany ośrodek sprzęgający. Na próbce znajdującej się po lewej stronie rysunku 9 nałożono profesjonalny sprzęgacz Ultragel-Il i nie zaobserwowano żadnych oznak korozji. Na drugiej próbce (na rys. 9 z prawej) pojawiła się korozja szczelinowa i powierzchniowa spowodowana niewłaściwym ośrodkiem sprzęgającym.

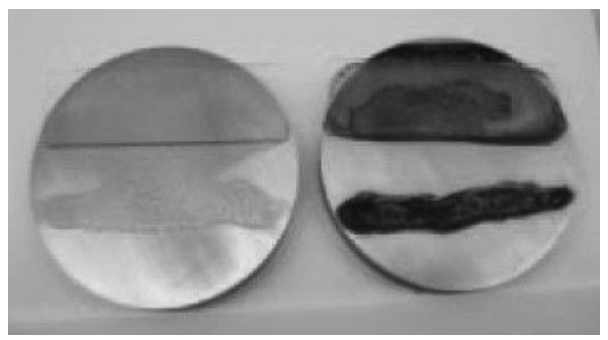

Rys. 9. Wyniki: z lewej próbka z Ultragel-II, z prawej próbka ze sprzęgaczem bez inhibitora korozji. Korozję szczelinową wywoływano w górnej części próbek

Fig. 9. Results of the experiment: on the left - specimen covered with Ultragel-II, on the right - specimen covered with couplant with inadequate corrosion inhibition. Crevice corrosion simulated under a glass microscope slide over the top bead of couplant on each coupon

\section{Podsumowanie i wnioski}

Powyżej zaprezentowano wpływ ośrodka sprzęgającego na przebieg badań ultradźwiękowych i wywoływanie zjawiska korozji. Na podstawie przytoczonych artykułów wykazano, że sprzęgacz ma za zadanie nie tylko eliminować warstwę powietrza spomiędzy głowicy i materiału badanego, ale jego właściwości (lepkość, gęstość, impedancja akustyczna) wpływają na wysokość amplitudy impulsów i wartość współczynnika tłumienia podczas badań ultradźwiękowych. Stwierdzono, że wraz ze wzrostem impedancji akustycznej ośrodka sprzęgającego zwiększa się amplituda sygnału oraz pozorny współczynnik tłumienia. Rzeczywisty współczynnik tłumienia jest zależny tylko od rodzaju badanego materiału.

Doświadczenia przeprowadzone przez firmy Sonatest i Sonotech wykazały ponadto, że rodzaj ośrodka sprzęgającego może mieć znaczący wpływ na powstanie zjawiska korozji na powierzchni pomiaru/badania. Stwierdzono, że odpowiedzialny za to jest dodatek, nazywany inhibitorem korozji. Ośrodek sprzęgający zawierający inhibitor korozji hamuje rozprzestrzenianie się korozji oraz zapobiega jej powstaniu, co jest bardzo istotne zwłaszcza, gdy sprzęgacz pozostaje po badaniach na badanym elemencie.

Na podstawie przedstawionych badań można stwierdzić, że najlepszymi ośrodkami sprzęgającymi są profesjonalne sprzęgacze do badań ultradźwiękowych. Nie dość, że są one tworzone z myślą o badaniach nieniszczących, co gwarantuje producent, mogą występować w różnej formie (proszku do rozrobienia lub gotowych żeli), dzięki czemu, w razie potrzeby, można je zagęścić lub rozrzedzić, to dodatkowo zawierają inhibitory korozji. Doświadczenia i praktyka przemysłowa sugerują, że profesjonalne ośrodki sprzęgające mają nad innymi przewagę - są bardziej uniwersalne, bezpieczniejsze dla badanych obiektów i często tańsze.

\section{Literatura}

[1] M.K. Lipnicki, „Badania Ultradźwiękowe, cz.1: Podstawy Teoretyczne”; wyd. 5; Gdańsk, 1998, Koli Sp. z o.o.

[2] M. Larsson, „Ten Criteria for Accurate Ultrasonic Couplant Selection”; Inspection Trends, Spring 2009, str. 24

[3] N. Netshidavhini, R.B. Mabuza „Effects of Various Couplants on Carbon Steel and Aluminium Materials Using Ultrasonic Testing"; 18-sta Światowa Konferencja Badań Nieniszczących, 16-20 kwietnia 2012, Durban, RPA
[4] Y.H. Kim i inni „A Study of the Couplant Effects on Contact Ultrasonic Testing"; Journal of the Korean Society for Nondestructive Testing, vol. 22, nr 6, 2002

[5] „Couplant vs Wallpaper Paste, Apllication Case Study"; Sonatest Ltd.; 2015 